\title{
EXPLORATION OF STRATEGY: OBJECTIVES, COMPETENCIES AND COMPETITIVE ADVANTAGE
}

\author{
Romualdas Ginevičius ${ }^{1}$, Renata Korsakiene் ${ }^{2}$ \\ Vilnius Gediminas Technical University, Sauletekio al. 11, 10223 Vilnius-40, Lithuania \\ E-mail:romualdas.ginevicius@adm.vtu.lt ; renatakorsa@takas.lt ${ }^{2}$
}

Received 2112 2004; accepted 15022005

\begin{abstract}
The notion that all companies should have a strategy is widely accepted. It has to be noted that a company's competitiveness describe objectives, competencies, competitive advantage and strategies. The linkages among objectives, competencies and competitive advantage are influenced by competitive forces in the market. The purpose of this paper is to propose a conceptual framework for analysis of a strategy and to present results of a survey carried out to explore the strategies of Lithuanian construction companies. The determinants of strategy such as objectives, competencies and competitive advantage can further be used as a guide for setting a strategic agenda for construction companies with different characteristics and operating in different markets.
\end{abstract}

Keywords: construction companies, objectives, competencies, competitive advantage, strategy

\section{Introduction}

The notion that company should have a clear strategy is widely accepted in strategic management literature. Some scholars point out that many strategic responses frequently fail to achieve the desired results, because these responses do not take into account how the organization's direction, product market focus and execution capabilities must fit together (Fuchs et al., 2000). Thus the strategic integration can be achieved due to the adoption of clear strategic perspective. It should be noted that the majority of research works in this field are based on the analysis of industrial companies and only some of them explore construction companies.

Companies working in construction market face more demanding business environment that is characterized as non stable and alien. For instance, Lithuanian construction market is influenced by political, social, economic, technological and other transformations currently undergoing in Eastern and Central Europe. On the other hand, the construction activity is influenced by changing costumers desires due to variations in taste and purchasing power. It should be noted that the intensive globalization and European integration provides a good incentive for construction companies to react adequately to the business environment changes, to spot them on time and initiate strategic decisions. Thus, the construction companies should have a clear strategy because individual company's success fully relies on implemented strategy.

While it is obvious that construction companies must have the strategy, it should be taken into account a uniqueness of such companies. These companies differ in their resources and knowledge. Thus, different strategies could be successful in the construction market.

It is important to stress that there is a big amount of literature on the subject of strategy. However, this work builds on the concept of Porter. He has raised the idea of three generic strategies: cost leadership strategy, differentiation strategy and focus strategy. According to some scholars, competitive strategies have clear applications for many types of construction enterprise (Betts \& Ofori (1992)).

The purpose of this paper is to propose a conceptual framework for analysis of a strategy and to present results of a survey carried out to explore the strategy 
of Lithuanian construction companies.

The paper is organized as follows. In section two we present the approaches to strategy. In section three we present the survey results of Lithuanian construction companies. The last section draws some major conclusions.

\section{The approaches to strategy}

The concept of strategy was raised in early sixties when the business environment became turbulent. Some scholars pointed out that perpetual struggle against uncertainty in the business environment are considered one of organisations' main problems (Thompson (1967)). Research works concentrating on business strategy were influenced by war theory and practice. Strategic principles, which foresee goals, mission, strengths and weaknesses, were formulated to solve battle problems. Strategy in this military sense is the art of war, or in another meaning, the art of general. Some authors point out that companies and armies have much in common. Dobson et al. claim that strategic thinking has been much influenced by military thinking about "the strategy hierarchy", of goals, policies and programmes (Dobson, Starkey \& Richards, 2004)). Indeed, the main difference between war and business strategy is that business strategy is formulated with purpose to compete in the market, while preconditions of war strategy are conflicts. However, despite the obvious importance of strategy and growing research papers in this area, there is little agreement on what a strategy is. No wonder Constantinos Markides claimed that: "within both business and academic circles, it would be quite miraculous to identify two people who share the same definition of strategy" (Markides (1999)).

The scholars started to use the term strategy in Game Theory. In Game Theory strategy represents a set of rules which influence the moves of players. For instance, one of the first definitions of strategy proposed by Chandler included the setting of longterm goals, determination of actions and allocation of resources in order to achieve these goals (Chandler (1962)). He claimed that strategy is a process which helps to adapt to the turbulent business conditions. On the other hand Ansoff pointed out the idea that company should have clear business activity and growth direction. Thus, he emphasized that company should make strategic decisions between products as well as markets (Ansoff (1965)). Ansoff and other scholars, who followed Ansoff's ideas, were concerned with strategy role on how to draw the boundaries of the company. However, contributions to modern business strategy have come from various disciplines, including economics, organizational behaviour and operations management (Hunt \& Lambe (2000)).

Porter has raised the idea of strategy as a way to achieve competitive advantage (Porter (1980)). His approach to competitive advantage is based on the idea that a strong position, which a company has in an industry, grants it competitive advantage (Porter (1985)). Thus the company's position in an industry sector is very important in analysing its competitive advantage. Referring to the structural approach Porter gives preference to the analysis of an industry (to five competitive forces).

According to Porter, competitive advantage is achieved by offering a higher value to the consumer, which is considerably higher than the cost of production. Besides that, the higher value is achieved by providing products at a lower price than do the competitors (comparing products that are of equivalent benefit) or by offering products that are of unique benefit to the consumer. Accordingly, Porter defines three generic strategies: cost leadership strategy, differentiation strategy and focus strategy.

Porter claims that companies are "stuck in the middle" if they try to do too many things. Thus, he emphasizes the importance of core competencies of organization and competitive forces influencing formulation of strategy.

Betts et al. argues that Porter's "competitive strategies have clear applications for many types of construction enterprise" (Betts \& Ofori (1992)). It is important to note that the basis of many construction markets form the open bidding systems. Therefore within construction business cycles exists opinion that only cost leadership is appropriate strategic approach. Despite this fact, it should be noted that cost leadership is not the only one strategic option, especially in recent times. The increasing concerns with quality and value for consumer make all three generic strategies relevant. The construction companies should take into account their strategic position in relation to markets and competitors and make decision which of the generic strategies is more appropriate.

It should be taken into account that the construction industry is project based industry. Thus, Lithuanian managers are more concerned with bidding strategies at the project level, rather than broad business strategy. The bidding strategies which are used by companies can vary according to client, country, bidding system and etc. In practice the decisions about the biding strategies are determined at the high level 
management. Therefore it is important that strategies taken at the project level reflect business level strategy. In general, construction companies can be divided into two groups: 1) companies that strive to achieve low cost advantage, and 2) companies that strive to achieve customer satisfaction by differentiation. These two strategies are common in construction industry and their success depends on competitive environment as well as strengths and weaknesses of the companies.

\section{The strategy survey of Lithuanian construction companies}

The following sections present the empirical research carried out in 2004. The data has been collected through questioning Lithuanian construction companies. Respondents were in positions of some authority in relation to their enterprise (directors and general managers). This survey focused on the impact of competitive forces, strategic issues and strategies utilized by construction companies. The aim of this research was to identify major strategic issues of Lithuanian construction companies and determine the strategic perspective.

For this purpose, standard questionnaires were prepared and sent to the members of Lithuanian Builders Association. The Lithuanian Builders Association was established in 1993 upon approval of the Government of the Republic of Lithuania. The Association was and is obligated to assist the companies in solving economic, legal, financial problems, representing them in executive authorities, contributing to legal acts and regulations drafting, consolidating forces to look for national and international markets. Today the Association includes 125 licensed companies and organizations involved in design work, construction, manufacturing of building materials and structures, training, insurance and some other businesses. The target group of research has been determined as the medium size and big size companies involved in construction works. These companies work with private costumers due to small number of projects financed by public sector. The majority of these companies have established the branches in foreign countries and have work experience with international costumers. The companies involved in design work, manufacturing of building materials and training were excluded from our target group. The total number of questionnaires distributed by mail or e-mail was 65 and total number of returned questionnaires was 30 . It should be noted that questions related with general information and strategic making process were included into questionnaire: size of a company, its age, major clients, existence of strategic plan, a style of strategic decision making. Furthermore, questions related with a company's objectives, a company's competences and competitive issues were included. The collected data were analysed using SPSS package.

\section{Analysis of survey results}

\section{Exploration of objectives}

The concept of mission has become one of the often used in discussions of strategy. Indeed, a mission statement can be thought as the first stage of the strategy planning process. Examination of company's mission from the point of view of owners has two aims. First, the company's mission determines the strategic course of company. Second, it defines the criteria for success.

There is a widely accepted notion that a company needs clarity on what it needs to do. On the other hand such clarity will deliver the outcomes that the customers and company's shareholders values. Therefore the company should take into account that its objectives determine the criteria for assessing its success. Chatterjee argues that competitive objectives of a company must be leading, specific and measurable (Chatterjee (2005)). The main long-range goal of company is to increase the wealth of its owners or, at least, to maintain it at its original size (Warszawski (1996)). A company can determine more specific economic objectives such as profitability, growth, survival and other objectives such as development of human resources, maximization of customer satisfaction, maximization of public benefits, etc. For instance, such objectives as development of human resources, maximization of customer satisfaction, maximization of public benefits are less economic in nature but their also contribute to the economic welfare.

Thus, one of the aims of survey was to identify the objectives of Lithuanian construction companies. The respondents were asked to rank the objectives using Likert scale (where 1 - the least important and 5 the most important). The results of findings are presented in Table 1.

It should be noted that the most important objectives of Lithuanian construction companies are to increase productivity, to maximize long-term profitability, to create a positive image in the market, to increase workload and to increase quality of works. These results correspond with results of survey which was carried out in Turkey by Dikmen and Birgonul (Dikmen \& Birgonul (2003)). The results allow 
Table 1. Objectives of Lithuanian construction companies

\begin{tabular}{|l|c|c|c|c|}
\hline Objective & Min & Max & Mean & Stand. deviation \\
\hline To increase productivity & 4 & 5 & 4,6 & 0,4983 \\
\hline To maximize long-term profitability & 4 & 5 & 4,6 & 0,4983 \\
\hline To create a positive company image & 4 & 5 & 4,5 & 0,5085 \\
\hline $\begin{array}{l}\text { To increase quality of construction } \\
\text { works }\end{array}$ & 4 & 5 & 4,5 & 0,5085 \\
\hline To increase workload & 4 & 5 & 4,4 & 0,4983 \\
\hline To maximize satisfaction of customer & 1 & 5 & 4,0 & 1,2034 \\
\hline To increase benefit of society & 3 & 4 & 3,2 & 0,4068 \\
\hline To develop structure of organization & 1 & 5 & 3,2 & 1,1860 \\
\hline To develop human resources & 1 & 5 & 3,2 & 1,0954 \\
\hline To maximize short-term profitability & 1 & 4 & 2,6 & 1,0372 \\
\hline
\end{tabular}

concluding that Lithuanian construction companies give priorities to economic objectives. Despite this fact, they also give priorities to less economic in nature objectives that contribute to the maximization of longterm profitability of companies.

The standard deviation of increasing productivity and maximizing long-term profitability are the lowest among others. It means that respondents agree about its importance level. The objective to create a positive company image takes the third place. Some authors claim that corporate image is the totality of stakeholders' perceptions of the way an organization presents itself, either deliberately or accidentally. Besides that, company's image is the result of the interaction of all the experiences, beliefs, feelings, knowledge and impressions that each stakeholder has about an organization (Topalian (1984), Markwick \& Fill (1997)).

To increase quality of construction works is the forth of the most important objectives. Arditi and Lee claims that the foundations of the quality orientation of company are defined at the corporate level (Arditi \& Lee (2003)). Other scholars argue that corporate culture which encourages quality conscious work environment promotes continues quality improvement through values, traditions and procedures (Goetsch \& Davis (1997)). Also, to increase the workload is very important objective of Lithuanian construction companies. It should be noted that this objective takes the fifth place and companies stress its importance due to small domestic market and very high competition.

The statistically significant relationships between objectives and their measures are presented in Table 2.

The high correlation coefficient calculated between the objectives is found to exist between the positive company image and satisfaction of costumer as well as increasing benefit to society. This implies that if a company aims to create positive image, it also strives to maximize satisfaction of costumer. It should be noted that companies that aim to create a positive image strive to develop organizational structure and human resources. The negative correlation coefficient calculated between objectives is found to exist between the positive company image and maximization of short-term profitability.

High correlation coefficient calculated between the objectives is found to exist between increasing workload and satisfaction of costumer as well as development of organizational structure.

As it was expected the strong correlation exists between quality of construction works and satisfaction of costumer. The companies who aim to increase quality of construction works also strive to increase productivity, to develop organizational structure and to increase benefit of society.

Lithuanian companies that tend to increase productivity also seek to increase long-term profitability, maximize satisfaction of costumer and to develop organizational structure. As it was expected there is strong relation between productivity and long term profitability.

It should be noted that high correlation coefficient calculated between objectives is found to exist between long term profitability and satisfaction of costumers as well as development of human resources.

\section{Exploration of competencies}

The ability to identify company's strengths and weaknesses is one of the major steps in strategic planning process. It should be noted that managers 
Table 2. Results of correlation analysis

\begin{tabular}{|l|c|c|c|c|c|c|c|c|c|c|}
\hline Objectives & 1 & 2 & 3 & 4 & 5 & 6 & 7 & 8 & 9 & 10 \\
\hline To create a positive company image & 1 & & & & & & & & & \\
\hline To increase workload &, $408^{*}$ & 1 & & & & & & & & \\
\hline $\begin{array}{l}\text { To increase quality of construction } \\
\text { works }\end{array}$ &, 200 &, $408^{*}$ & 1 & & & & & & & \\
\hline To increase productivity &, $408^{*}$ &, 250 &, $816^{* *}$ & 1 & & & & & & \\
\hline To maximize long-term profitability &, 000 &, 250 &, $408^{*}$ &, $583^{* *}$ & 1 & & & & & \\
\hline $\begin{array}{l}\text { To maximize satisfaction of } \\
\text { customer }\end{array}$ &, $507^{* *}$ &, $518^{* *}$ &, $507^{* *}$ &, $690^{* *}$ &, $690^{* *}$ & 1 & & & & \\
\hline $\begin{array}{l}\text { To develop structure of } \\
\text { organization }\end{array}$ &, $686^{* *}$ &, $735^{* *}$ &, $514^{* *}$ &, $490^{* *}$ &, 315 &, $652^{* *}$ & 1 & & & \\
\hline To develop human resources &, $743^{* *}$ &, $417^{*}$ &, $557^{* *}$ &, $720^{* *}$ &, $531^{* *}$ &, $863^{* *}$ &, $764^{* *}$ & 1 & & \\
\hline To maximize short-term profitability &,$- 392^{*}$ &,- 080 &, $392^{*}$ &, 080 &, 080 &, 000 &,- 269 &,- 109 & 1 & \\
\hline To increase benefit of society &, $500^{* *}$ &, 107 &, $500^{* *}$ &, $408^{*}$ &,- 102 &, 211 &, $557^{* *}$ &, $604^{* *}$ &,- 049 & 1 \\
\hline
\end{tabular}

* at the 5\% level of significance

** at the $1 \%$ level of significance

are not used to think in terms "strengths and weaknesses". However, according Stevenson, the evaluation which they make in determining areas for action reflect judgment of their organizations capabilities related to either a competitive threat or a belief about what "ought to be" (Stevenson, 1976).

Thus, one of the aims of survey is to identify strengths and weaknesses of Lithuanian construction companies. The respondents were asked to rank strengths and weaknesses using Likert scale (where 1 - the least important and 5 - the most important). The results of findings are presented in Table 3.

It should be noted that the major strengths of Lithuanian construction companies are experience in the market, quality of works, company image and technical capabilities. The ability to work with low cost, financial resources, relations with competitors and marketing are the major weaknesses of companies.

Many of the questioned companies work in the market longer than ten years. Thus, companies stress experience as the major strength. It is a wide accepted notion in the construction business that an experience is a knowledge-based advantage. According to some scholars, organizational routines developed from experience offer competitive advantage to established and experienced firms over new comers (Fu et al., 2002). The experience in the market influence higher quality of works, better technical capabilities and better company image.

Table 3. Strengths and weaknesses of Lithuanian construction companies

\begin{tabular}{|l|c|c|c|c|}
\hline Strengths and weaknesses & Min & Max & Mean & Stand. deviation \\
\hline Experience in the market & 4 & 5 & 4,8 & 0,4068 \\
\hline Quality of works & 4 & 5 & 4,4 & 0,4983 \\
\hline Company image & 3 & 5 & 4,4 & 0,6747 \\
\hline Technical capabilities & 4 & 5 & 4,3 & 0,4661 \\
\hline Human resources & 3 & 5 & 4,2 & 0,6103 \\
\hline Relations with costumers & 3 & 4 & 3,9 & 0,3051 \\
\hline Managerial capabilities & 2 & 5 & 3,7 & 0,9154 \\
\hline Organizational structure & 3 & 5 & 3,6 & 0,6747 \\
\hline Marketing & 2 & 5 & 3,6 & 0,9322 \\
\hline Relations with competitors & 3 & 4 & 3,6 & 0,4983 \\
\hline Financial resources & 2 & 4 & 3,0 & 0,7878 \\
\hline Ability to work with low costs & 1 & 4 & 2,9 & 0,9595 \\
\hline
\end{tabular}


The statistically significant relationships between strengths and weaknesses and their measures are presented in Table 4.

The high correlation coefficient calculated between the strength and weaknesses is found to exist between the experience in the market and relations with customer as well as organizational structure and marketing. This implies that if a company has experience in the market, it also has better relations with costumers and better marketing efforts.

As it is expected the strong correlation exists between company image and technical capabilities as well as relations with costumers, managerial capabilities, organizational structure and marketing. If company is confident about its image it also is confident about managerial capabilities, organizational structure and marketing.

The negative correlation coefficient calculated is found to exist between quality of works and managerial capabilities, between human resources and organizational structure as well as the ability to work with low costs.

\section{Exploration of competitive advantage}

Many scholars argue that competitive advantage is determined by the valuable resources of company, such as its collective skills and competences (Barney (2001), Lopez (2001)). Lado and Wilson say: „The firm is viewed as a nexus of resources and capabilities that are not free bought and sold in the spot market. To the extent that these firm-specific resources and capabilities yield economic benefits that cannot be perfectly duplicated through competitors' actions, they may be potent sources of sustained competitive advantage"(Lado \& Wilson (1994)).

Thus, it is necessary to point out that the conditions for the optimal growth of company are created by properly balancing the use of available resources and competences. The company seeking constant growth has to advance available resources and competences and look for new ones constantly.

Moreover, there is an opinion that the unique resources of a company are directly related to its higher results. Unique, difficult to imitate and immobile resources are appreciated because they generate economical rent. The authors who have been developing resource-based theory claim that the relationship between competitive advantage and results is obviously direct, because it does not make a precise distinction between low prices, differentiation or other types of competitive

Table 4. Results of correlation analysis

\begin{tabular}{|l|c|c|c|c|c|c|c|c|c|c|c|c|}
\hline $\begin{array}{l}\text { Strengths and } \\
\text { weaknesses }\end{array}$ & 1 & 2 & 3 & 4 & 5 & 6 & 7 & 8 & 9 & 10 & 11 & 12 \\
\hline $\begin{array}{l}\text { Experience in the } \\
\text { market }\end{array}$ & 1 & & & & & & & & & & & \\
\hline Quality of works &, 282 & 1 & & & & & & & & & & \\
\hline Company image &, $430^{*}$ &,- 267 & 1 & & & & & & & & & \\
\hline $\begin{array}{l}\text { Technical } \\
\text { capabilities }\end{array}$ &, 195 &,- 263 &, $804^{* *}$ & 1 & & & & & & & & \\
\hline Human resources &,$- 411^{*}$ &, 069 &,- 271 &,$- 384^{*}$ & 1 & & & & & & & \\
\hline $\begin{array}{l}\text { Relations with } \\
\text { costumers }\end{array}$ &, $527^{* *}$ &,- 089 &, $726^{* *}$ &, $492^{* *}$ &, 087 & 1 & & & & & & \\
\hline $\begin{array}{l}\text { Managerial } \\
\text { capabilities }\end{array}$ &, $430^{*}$ &,$- 582^{* *}$ &, $667^{* *}$ &, $704^{* *}$ &,$- 671^{* *}$ &, $408^{*}$ & 1 & & & & & \\
\hline $\begin{array}{l}\text { Organizational } \\
\text { structure }\end{array}$ &, $563^{* *}$ &,- 190 &, $824^{* *}$ &, $724^{* *}$ &,$- 509^{* *}$ &, $579^{* *}$ &, $691^{* *}$ & 1 & & & & \\
\hline Marketing &, $584^{* *}$ &,- 066 &, $536^{* *}$ &, $364^{*}$ &,$- 415^{*}$ &, $739^{* *}$ &, $553^{* *}$ &, $592^{* *}$ & 1 & & & \\
\hline $\begin{array}{l}\text { Relations with } \\
\text { competitors }\end{array}$ &, 323 & -327 &, 111 &, 075 &, $477^{* *}$ &, $408^{*}$ &, 250 &, 055 &,- 075 & 1 & & \\
\hline Financial resources &, $430^{*}$ &, 218 &, 259 &, 302 &,- 035 &, 272 &, 111 &, 218 &, 201 &, $667^{* *}$ & 1 & \\
\hline $\begin{array}{l}\text { Ability to work } \\
\text { with low costs }\end{array}$ &, 264 &, 089 &, $408^{*}$ &, $431^{*}$ &,$- 519^{* *}$ &,- 167 &, 272 &, $535^{* *}$ &,- 123 &, 102 &, $408^{*}$ & 1 \\
\hline
\end{tabular}

$*$ at the $5 \%$ level of significance

$* *$ at the $1 \%$ level of significance 
advantage. If a company has valuable, rare and difficult to emulate resources, higher results are guaranteed.

Very often resources available to a company and allowing it to create goods productively and present them effectively to the market, and thus create a greater value in a segment of market are tangible and intangible (Hunt \& Morgan (1995)). Wernerfelt claim that „by a resource is meant anything which could be thought of as strength or a weakness of a given firm. More formally, a firm's resources at a given time could be defined as those (tangible and intangible) assets which are tied semi permanently to the firm. Examples of resources are: brand names, in-house knowledge of technology, employment of skilled personnel, trade contracts, machinery, efficient procedures, capital“(Wernerfelt (1984)). Hunt and Morgan grouped tangible resources into financial, physical, legal, human, organisational, informational and relational resources (Hunt \& Morgan (1995)).

Thus, one of the aims of survey is to identify the sources of competitive advantage of Lithuanian construction companies. The respondents were asked to rank the sources of competitive advantage using Likert scale (where 1 - the least important and 5 the most important). The results of findings are presented in Table 5 .

It should be noted that the major sources of competitive advantage of Lithuanian construction companies are technical capabilities, managerial capabilities, experience, quality, cost and time.

Some scholars point out that capabilities allow a company to distinguish itself constantly on the dimensions that are important to its costumers (Bartmess \& Cerny (1993)). As it was expected management capability and production capability, or the ability to ensure competitive priorities, such as quality, cost and time are important sources of competitive advantage among Lithuanian construction companies. It means that management in Lithuanian construction industry become more "professional" and companies operate in more market - driven manner. However, the implementation of innovations takes the last place and the technical capabilities take the first place as a source of competitive advantage due to the traditional thinking in construction industry. It should be noted that the management of companies do not take into account implementation of innovations and do not understand it significance.

The statistically significant relationships between sources of competitive advantage and their measures are presented in Table 6.

The high correlation coefficient calculated between the sources of competitive advantage is found to exist between quality and technical capabilities. This implies that if a company achieves higher quality, it also has better technical capabilities.

As it was expected the strong correlation exists between cost and time and implementation of innovations. If company strives to achieve low cost and shorter time to market as a source of competitive advantage it should take into account implementations of innovations.

The negative correlation coefficient calculated is found to exist between quality and experience as well as cost and time. Also it is important to stress that the negative correlation coefficient calculated is found to exist between experience and relations with customers. This implies that companies working in the market for the longer period have established certain contacts and relations with major clients that guarantee more contracts.

Table 5. Sources of competitive advantage of Lithuanian construction companies

\begin{tabular}{|l|c|c|c|c|}
\hline $\begin{array}{l}\text { Sources of competitive } \\
\text { advantage }\end{array}$ & Min & Max & Mean & Stand. deviation \\
\hline Technical capabilities & 4 & 5 & 4,2 & 0,4068 \\
\hline Managerial capabilities & 4 & 5 & 4,2 & 0,4068 \\
\hline Experience & 4 & 5 & 4,3 & 0,4661 \\
\hline Quality & 4 & 5 & 4,5 & 0,5085 \\
\hline Cost and time & 3 & 5 & 4,1 & 0,5477 \\
\hline Financial resources & 3 & 5 & 4,4 & 0,6747 \\
\hline Relations with customers & 3 & 5 & 4,5 & 0,6823 \\
\hline Implementation of innovations & 3 & 5 & 3,8 & 0,8867 \\
\hline
\end{tabular}


Table 6. Results of correlation analysis

\begin{tabular}{|l|c|c|c|c|c|c|c|c|}
\hline $\begin{array}{l}\text { Sources of competitive } \\
\text { advantage }\end{array}$ & 1 & 2 & 3 & 4 & 5 & 6 & 7 & 8 \\
\hline Quality & 1 & & & & & & & \\
\hline Relations with customers &, $447^{*}$ & 1 & & & & & & \\
\hline Financial resources &, 302 &, 225 & 1 & & & & & \\
\hline Technical capabilities &, $500^{* *}$ &, 000 &, 075 & 1 & & & & \\
\hline Managerial capabilities &, 000 &, 000 &, 075 &, $375^{*}$ & 1 & & & \\
\hline Experience &,- 218 &,$- 488^{* *}$ &,- 066 &, 218 &, 218 & 1 & & \\
\hline Cost and time &,- 186 &,$- 692^{* *}$ &, 168 &, 093 &, $371^{*}$ &, 284 & 1 & \\
\hline $\begin{array}{l}\text { Implementation of } \\
\text { innovations }\end{array}$ &, 229 &,- 342 &, $484^{* *}$ &, $461^{*}$ &, $401^{*}$ &, $401^{*}$ &, $469^{* *}$ & 1 \\
\hline
\end{tabular}

* at the $5 \%$ level of significance

** at the $1 \%$ level of significance

\section{Exploration of strategies}

As it was pointed above construction companies apply three generic strategies: cost leadership strategy, differentiation strategy and focus strategy. The research has shown that $68 \%$ of Lithuanian companies apply differentiation strategy. The respondents declared that they offer services that are of unique benefit to costumer. $21 \%$ of respondents declared that they have focus strategy and $11 \%$ of respondents declared that they have cost leadership strategy.

The essence of differentiation strategy is to provide more attractive and more valuable services than competitor's services. It should be noted that it does not mean that low costs issues are not considered, rather reducing costs is not the primary objective. There are many possibilities to apply differentiation strategy in construction industry. Thus, Lithuanian construction companies offer faster project completion, higher quality services, higher standards and more extensive services to costumers.

Faster project completion is very attractive to costumer in terms of returns. Besides that, it helps to reduce unproductive time and in terms of profitability is attractive to the construction company. The construction companies increase its value by offering higher quality services - better aesthetic appearance, fewer repairs, fewer faults, higher costumer satisfaction and lower future maintenance costs.

The contracting service to costumer is to complete the project according drawings and specifications. However, the construction companies can offer more services by advising to costumer in various stages of design, in financing the project, in planning operations and etc.
The essence of cost leadership strategy is to be less expensive than competitors. The cost leadership can be obtained by a combination of such factors as selection of suppliers, tight control, and training of employees, technological advance and standardization.

A major share of the construction projects belongs to materials supplied by suppliers. Thus, Lithuanian construction companies pay big attention to such factors as quality of materials, payment terms, price discount and etc.

Tight control requires from construction companies to set up the strict standards and very tight control of labor and material inputs. Training of employees in working procedures can also contribute to the cost reduction.

The construction companies often choose to specialize in providing certain services to the costumers. For example, the construction company can specialize in certain types of projects. It can develop special work methods, to choose the most advantageous suppliers and in such a way to lower costs.

However, it should be noted that cost leadership is not very popular among big and medium size Lithuanian construction companies. Due to high competition in the market and the application of the same methods, low cost strategy influences the decrease of profitability.

The essence of focus strategy is based on applying cost leadership or differentiation to a narrow segment of the market. However, it should be noted that focus strategy is more appropriate to small companies. Such companies can restrict the activity to only certain types of customers, projects or geographical areas. 


\section{Conclusions}

The intensive globalization and integration into the EU provides a good incentive for Lithuanian construction companies to react adequately to the business environment changes, to spot them on time and initiate strategic decisions. Thus, the construction companies should have a clear strategy because individual company's success fully relies on implemented strategy.

It has to be noted that a company's strategy and its competitiveness describe objectives, competencies, and competitive advantage. It should be taken into account that the construction industry is project based industry. Nowadays managers of companies are more concerned with bidding strategies at the project level, rather than broad business strategy. Therefore it is important that strategies taken at the project level reflect business level strategy.

A survey of Lithuanian construction companies reveals that the most important objectives of companies are to increase productivity, to maximize long-term profitability, to create a positive image in the market, to increase workload and to increase quality of works. It means that Lithuanian construction companies give priorities to economic objectives. Despite this fact, they also give priorities to less economic in nature objectives that contribute to the maximization of longterm profitability of companies.

Analysis of competencies reveals that the major strengths of Lithuanian construction companies are experience in the market, quality of works, company image and technical capabilities. The ability to work with low cost, financial resources, relations with competitors and marketing are the major weaknesses of companies.

The technical capabilities, managerial capabilities, experience, quality, cost and time are the major sources of competitive advantage of Lithuanian construction companies.

According to survey results, differentiation strategy is the most frequently applied strategy by Lithuanian construction companies. The essence of differentiation strategy is to provide more attractive and more valuable services than competitor's services. Thus, Lithuanian construction companies offer faster project completion, higher quality services, higher standards and more extensive services to costumers.

The survey analyzes only medium and big companies. Thus, such framework can be used as a guide for setting a strategic agenda for construction companies with different characteristics and operating in different markets.

\section{References}

1. Ansoff, H. I. Corporate strategy: An analytic approach to business policy for growth and expansion. McGrawHill, New York, 1965.

2. Arditi D. \& Lee D. Assessing the corporate service quality performance of design - build contractors using quality function deployment. Construction Management and Economics, 21, 2003, p.175-185.

3. Barney, Jay B. Resource-based theories of competitive advantage: A ten - year retrospective on the resourcebased view. Journal of management, 27, 2001, p.643650.

4. Bartmess, A.; Cerny, K. Building competitive advantage through a global network of capabilities. California management review, 35(2), 1993, p. 78-103.

5. Betts, M. \& Ofori G. Strategic planning for competitive advantage in construction. Construction Management and Economics, 10, 1992, p. 511-532.

6. Chandler, A. D. Strategy and structure: Chapters in the history of the industrial enterprise. MIT Press, Cambridge, Mass, 1962.

7. Chatterjee S. Core objectives: Clarity in designing strategy. California Management Review, 47(2), 2005, p. $33-50$.

8. Dikmen I. \& Birgonul T. Strategic perspective of Turkish construction companies. Journal of management in engineering, 19 (1), 2003, p. 33-40.

9. Dobson P., Starkey K. \& Richards J. Strategic management. Issues and cases. Blackwell Publishing, 2004.

10. Fu, W., K.; Drew, Derek, S.; Leo, P., H. The effect of experience on contractors' competitiveness in recurrent bidding. Construction Management and Economics, 20, 2002, p.655-666.

11. Fuchs, Peter H.; Mifflin, Kenneth E.; Miller, Danny; Whitney, John O. Strategic integration: Competing in the age of capabilities. California management review, 42(3), 2000, p. 118-148.

12. Goetsch, D.L. \& Davis, S.B. Introduction to Total Quality: Quality management for production, processing and Services. Prentice-Hall, Inc., Upper Saddle River, N.Y, 1997.

13. Hunt, Shelby D., Lambe, C. Jay Marketing's contribution to business strategy: market orientation, relationship marketing and resource-advantage theory. International Journal of management Reviews, 2(1), 2000, p.17-43.

14. Hunt, Shelby D. \& Morgan, Robert M. The comparative advantage theory of competition. Journal of Marketing, 59, 1995, p. 1-15. 
15. Lado, A.A.; Wilson, M.C. Human resource Systems and Sustained Competitive advantage: A Competency-Based perspective. Academy of Management Review, 19, 4, 1994, p.699-727.

16. Lopez, Vincente, A. An overview of the resource-based view (RBV) of the firm, drawing on recent Spanish management research'. Irish journal of management, 22(2), 2001, p. 105-120.

17. Markides, Constantinos C. In Search of Strategy. Sloan Management Review, 40(3), 1999, p. 6-7.

18. Markwick, N. and Fill, C. Towards a framework for managing corporate identity. European Journal of Marketing, 31(5), 1997, p. 396-409.

19. Porter, M. E. Competitive advantage. N.Y.: London: Free Press Collier Macmillan, 1985.

20. Porter, M. E. Competitive strategy: Techniques for analyzing industries and competitors. Free Press, New York, 1980.

21. Stevenson, Howard, H. Defining Corporate Strengths and Weaknesses. Sloan management review, 17(13), 1976, p. 51-69.

22. Thompson, J.D. Organizations in action. McGraw-Hill, New York, 1967.

23. Topalian, A. Corporate identity: beyond the visual overstatements. International Journal of Advertising, 3, 1984, p.55-62.

24. Warszawski, A. Strategic planning in construction companies. Journal of construction engineering and management, 122(2), 1996, p. 133-140.

25. Wernerfelt B. A Resource-Based View of the Firm. Strategic Management Journal, 5, 1984, p. 171-180. 